Rok XVI (2021) | 1 (31) | S. 225-234

https://doi.org/10.12797/LV.16.2021.31.17

Lidia Przymuszała (1)

Uniwersytet Opolski, Opole

Iprzymuszala@uni.opole.pl

\title{
„ROZKOSZ DLA ZMYSŁÓW", CZYLI JĘZYK KART DAŃ
}

Słowa klucze: kulinaria, karta dań (menu), współczesna polszczyzna

Keywords: cuisine, menu, modern Polish language

Od jakiegoś czasu daje się zauważyć niespotykany dotąd wzrost zainteresowania wśród zwykłych „zjadaczy chleba” sztuką kulinarną. Sformułowanie „sztuka kulinarna" jest tu świadome i celowe, gdyż już dawno wszystko to, co związane z jedzeniem, przyrządzaniem, gotowaniem i spożywaniem posiłków przestało być tylko niezbędną czynnością służącą do zaspokojenia głodu, a stało się czynnością bardzo świadomą i wyrafinowaną.

Przejawy zmiany podejścia do jedzenia i gotowania widać na różnych płaszczyznach. Wyrazem tego są np. liczne, cieszące się niezwykle dużą oglądalnością programy kulinarne o bardzo zróżnicowanej formule ${ }^{1}$, poświęcone tematyce kulinarnej blogi i fora internetowe, na których internauci wymieniają się przepisami i swoim kulinarnym doświadczeniem, a także ogromna liczba książek i poradników kucharskich dostępnych na polskim rynku wydawniczym, które w niczym nie przypominają dawnych książek kucharskich w tradycyjnym wydaniu i których tematyka wykracza daleko poza sferę kulinariów. Z uwagi na swą zawartość, szatę graficzną, a zwłaszcza przyciągające wzrok - wręcz artystyczne - zdjęcia potraw są one raczej albumami kulinarnymi niż zwykłymi jedynie zbiorami przepisów.

1 Od roku 2015 na antenie różnych stacji telewizyjnych (m.in. TVP, TVN, TVN Style, TV Puls, Polsat, Food Network) można było obejrzeć ponad setkę programów kulinarnych. 
Fotografie gotowych potraw, wykonywane często przez znanych i wybitnych twórców, nie są w nich wyłącznie barwnym dodatkiem, ale funkcjonują na równych prawach z tekstami-przepisami. Książki te nie tylko pełnią funkcję użytkową, ale także cieszą oko, zachęcając „smakowitymi” ilustracjami do wypróbowania danej receptury.

Różne przejawy żywego zainteresowania kulinarną sztuką pokazują jednoznacznie, że przyrządzanie, a potem spożywanie potraw ze zwykłej, mało znaczącej codziennej czynności dla wielu stało się dziś rytuałem, celebracją czy wręcz życiową pasją.

$\mathrm{W}$ ostatnich czasach zmieniło się nie tylko podejście do gotowania i kulinariów, ale zmienił się też język, którym o potrawach się mówi³. Wyraźnym tego przykładem są karty dań restauracyjnych ${ }^{4}$.

Podobnie jak ilustracje w książkach kucharskich czy zdjęcia umieszczane na kulinarnych blogach sposób opisu potrawy ma zachęcić klienta do wyboru konkretnego dania.

Jedzenie, doświadczanie smaku potrawy odbywa się bowiem nie tylko fizycznie, przy użyciu języka, ale i poprzez język. To, jak pokazuje się jedzenie na zdjęciach potraw lub w jaki sposób się je opisuje, np. w menu, daje równie intensywne doznania, co sama degustacja. Świadomość tej zależności - smaku i słowa - posiadają przynajmniej niektórzy restauratorzy, czego świadectwem jest sposób opisu potraw w kartach dań oferowanych klientom przez restauracje.

Jaki zatem jest język współczesnych kart dań? Przeprowadzone analizy, których podstawą było menu kilku wybranych restauracji ${ }^{5}$, pozwalają na sformułowanie pewnych spostrzeżeń ${ }^{6}$.

2 Oczywiście nie mówię tu o tradycyjnej kulturze ludowej, w której jedzenie od zawsze otoczone było szczególnym pietyzmem, przygotowywanie i spożywanie posiłków stanowiło nieodłączny element wielu obrzędów i rytuałów, a poszczególne pokarmy miały swoją wymowę i symbolikę.

3 Zob. na ten temat np.: Dąbrowska 1998; Lewiński 1998; Lesz-Duk 2002; Bralczyk 2004.

4 Menu jako gatunek językowo-kulturowej wypowiedzi było przedmiotem opisu w artykule Marty Wójcickiej (2010).

5 Jako materiał do analizy wykorzystano karty dań następujących restauracji: „Bida” (Opole, Wrzoski), „La Strada” (Kraków), „Galicja” (Wrocław), „Konfitura” (Rzeszów), „AleGloria” (Warszawa), „Oberża pod Czerwonym Wieprzem” (Warszawa), „Mazurkowa Chata” (Jelenia Góra). Zob.: http://www.karczmabida.com/menu/opole/; http://www.lastrada.com.pl/menu-desery.html; http:// restauracjagalicja.pl; http://www.restauracjakonfitura.pl/kontakt.html; http://alegloria.pl/menu; http://www.czerwonywieprz.pl/pl/menu.html; http://www.mazurkowachata.pl/zarelko.

$6 \mathrm{~W}$ artykule analizie poddano sposoby opisywania dań w kartach restauracyjnych. Poza obszarem badań znalazły się natomiast nazwy dań oraz deklarowany charakter restauracji (lokale serwujące kuchnię staropolską, regionalną, włoską itp.), mający istotny wpływ na językowy kształt menu. Całościowa analiza wszystkich aspektów, pokazujących restauracyjną kartę dań jako tekst reklamowy dostosowany do różnych upodobań współczesnych konsumentów, przekracza ramy niniejszego tekstu. 
Jak wiadomo, o efektywności sztuki kulinarnej decydują doznania estetyczne związane ze wszystkimi zmysłami człowieka. Nie dziwi zatem fakt, że w opisach dań sięga się po nazwy sensoryczne, odwołujące się do cech organoleptycznych potrawy (Witaszek-Samborska 2005: 150), których zadanie polega na odpowiednim pobudzeniu nie tylko zmysłów wzroku, smaku i węchu, ale także dotyku, a nawet słuchu potencjalnego klienta.

W opisach potraw dominują odniesienia do zmysłu wzroku, stąd tak liczne w nich konstrukcje z określeniami barw i kształtów potrawy lub poszczególnych jej składników, np.:

rumiana bagietka; czerwień peperoncino; różowe krewetki; czarne nitki makaronu nero di seppia; wstęgi różowego makaronu; białe tagliatelle; złocista cebulka; bursztynowy rosół; barszcz rubinowy; złocisty pierożek; zrumieniona cebulka; plastry bakłażana podawane na kolorowej sałacie; złota panierka; wielobarwny wianek warzyw z patelni; łódeczki ziemniaczane; krążki czerwonej cebuli; grillowane kapelusze pieczarek; babeczki z ryżu białego.

Równie często co wrażenia wzrokowe, aktywizowane są doznania związane ze smakiem ${ }^{7}$. Obok ogólnych leksemów oraz konstrukcji o znaczeniu melioratywnym, jak smaczny, smakowicie, do smaku, w materiale odnotowano szereg przymiotników szczegółowych nazywających doznania smakowe (pikantny, ostry, kwaśny, soczysty, winny itp.), np.:

smaczna wariacja swojskiej kaszanki z jajkiem; soczysty sos ze świeżych pomidorów; nuta ostrej papryczki peperoncino; pikantny gulasz rybny; krewetki z nutą czosnkową; bulion suto zaprawiony czosnkiem; gulasz wołowy z cebulą i papryką na ostro; glazurowane foie gras z ostrą sałatą z truskawek; kaczka faszerowana kwaśnymi jabłkami; flaki wołowe majerankiem do smaku zaprawiane; polędwiczka balsamowana w kawałkach smakowicie obsmażona, soczysta i winna; gulasz z papryką lekko zaostrzoną; liście soczystej rukoli; słodycz gruszki.

Ze smakiem potrawy nieodłącznie związany jest jej zapach. Oba te doznania, odczuwanie smaku i zapachu, ściśle się ze sobą wiążą i przenikają nawzajem, co widać w menu w opisach potraw:

aromatyczny krem ze świeżych pomidorów; sprężysty makaron penne w kompozycji grilowanego kurczaka i pachnących borowików; filet $\mathrm{z}$ sandacza $\mathrm{z}$ dodatkiem piure z owoców morza, gratyną z sera białego $\mathrm{z}$ awokado i kremem z marchwi aromatyzowanym korą cynamonową; krewetki o silnym aromacie czosnkowym; delikatne plastry łososia skropione oliwą o nucie cytrynowej; cieniutkie plastry marynowanej piersi kaczej z dodatkiem aromatycznej oliwy truflowej, całość przepełnia aromat białego wina i sosu śmietanowego; pachnące grzyby; białe tagliatelle z cząstkami

$7 \quad$ Na ten temat zob. Mitrenga 2014. 
wędzonego łososia w sosie śmietanowym; aromatyczna zupa z leśnych grzybów; różnorodność owoców morza o intensywnym zapachu czosnku; łosoś różowy zapieczony z pachnącymi grzybami w śmietanie; bursztynowy rosół uperfumowany $\mathrm{z}$ kołdunami jagnięcymi; prawdziwkowa $\mathrm{z}$ borowikami, lasem pachnąca; filet $\mathrm{z}$ dorsza morską wonią pachnący.

Doznania smakowe i zapachowe oddają nie tylko przymiotniki prymarnie związane ze smakiem i zapachem (ostry, pikantny; aromatyczny, pachnacy), ale także wyliczenia dodatków i przypraw użytych do wykonania potrawy czy wskazanie sposobu jej przyrządzenia, które silnie ewokują określone doznania smakowe i zapachowe:

gołąbki faszerowane kurkami i kaszą perłową utopione w rosole z warzyw na smaku z kiszonej kapusty, zasypane koprem; tatar ze śledzi z orzechami i imbirem na miodowym pumperniklu; Vitello Tonnato z orzechami laskowymi prażonymi na maśle; plastry polskiego łososia wędzonego dymem z drzewa wiśniowego; pierogi z kaszanką i cynamonem; kołduny utopione w bulionie $\mathbf{z}$ lubczykiem i octem dębowym; kotleciki jagnięce marynowane w rozmarynie; polędwica na grillu sprażona podawana $z$ wiejskim masłem i świeżo utartym czosnkiem; skoki z królika duszone w śmietanie $\mathbf{z}$ dodatkiem tymianku; zupa ze świeżych pomidorów, serwowana z grzankami i serem feta $\mathrm{z}$ dodatkiem czosnku i bazylii.

Samo wyliczenie użytych składników, jak: miód, czosnek, orzechy, koper, imbir, lubczyk, tymianek, bazylia, rozmaryn, lub wskazanie technik obróbki potrawy, jak np. wędzenie czy prażenie, wywołuje określone (bardzo wyraziste) i pożądane doznania smakowe.

Zwiększeniu atrakcyjności potrawy służą także odwołania do zmysłu dotyku. W tym celu wykorzystuje się w opisie nazwy określające temperaturę, konsystencję, delikatność bądź miękkość potrawy, np.:

lody waniliowe z gorącymi truskawkami; szarlotka na ciepło; gorące naleśniki; warzywa al dente; sprężysty makaron penne w kompozycji grillowanego kurczaka i pachnących borowików; łyżka gęstej wiejskiej śmietany; tradycyjne naleśniki z wiejskim białym serem i puszystą śmietaną; krem z mięsistych pomidorów; krucha sałata; pieczeń cielęca krucha i delikatna w domowym sosie koperkowym; gruby plaster miękkiego karczku z pieca w sosie utopiony.

Często stosowanym zabiegiem językowym jest wprowadzanie w menu określeń mówiących o jakości i intensywności doznań smakowych, zapachowych czy dotykowych. Gradację tychże doznań, od bardzo wyraźnych, intensywnych po delikatne, ledwo wyczuwalne, uzyskuje się poprzez użycie określonych leksemów - w tym spieszczeń (pieczarki w sosiku białym z gara prosto na polędwiczkę mięciutka polane; poślednie zioberka duszone kruchutkie w sosie pieczeniowym skąpane; mięciutka golonka $z$ warzywami piwkiem zalana na kapuście zasmażanej serwowana) lub za pomocą konstrukcji o charakterze porównawczym (barszcz czerwony jak rubin określenie to podkreśla nie tylko głębię koloru, ale także szlachetność wywaru). 
Różnorodność i pełnię zapachów oddaje najchętniej stosowany, bardzo pojemny znaczeniowo przymiotnik „aromatyczny” ('przyjemnie pachnący, pełen aromatu; wonny' ale także 'silnie, wyraziście pachnący'), zaś subtelność, delikatność doznań zapachowych i/lub smakowych wyrażają zwykle rzeczowniki nuta, kropla, akcent, przymiotniki lekki, intensywny, silny oraz czasownik przepetniać:

smażone krewetki z nutą czosnkową; nuta ostrej papryczki peperoncino; delikatne plastry łososia skropione oliwą o nucie cytrynowej; na koniec krople sosu bazyliowego; pierś kurczęcia $\mathbf{z}$ kroplą pesto; różowe krewetki w sosie śmietanowym $\mathbf{z}$ akcentem natki pietruszki; gulasz z papryką lekko zaostrzoną; różnorodność owoców morza o intensywnym zapachu czosnku; krewetki o silnym aromacie czosnkowym; całość przepełnia aromat białego wina; owoce morza o intensywnym zapachu czosnku.

W opisach dań najrzadziej pojawiają się odwołania do wrażeń słuchowych. W badanym materiale przestrzeń słuchu aktywizowana jest przez leksemy należące bezpośrednio do pola semantycznego kulinariów - chrupiący oraz skwierczący:

chrupiące ziemniaki; chrupiące grzanki; chrupiący bekon; sałata á la Cezar z rumianym kurczakiem, ananasem i skwierczącym bekonem; chrupiąca grillowana kaszanka; pierś z perliczki marynowana sokiem z winogron z chrupiącą skórką glazurowaną nalewką z pigwy;

a także przez terminy należące prymarnie do świata muzyki:

kompozycja aksamitnej oczyszczającej owocowej słodyczy; makaron penne w kompozycji grillowanego kurczaka; orzeźwiająca nuta białych winogron; smaczna wariacja swojskiej kaszanki z jajkiem; pstrąg filetowany podany z czarnym ryżem $\mathrm{w}$ akompaniamencie krewetek black-tiger, musem $\mathrm{z}$ kopru włoskiego $\mathrm{z}$ delikatną nutką szafranu.

Poza odwołaniami do cech organoleptycznych potraw, mającymi pobudzić apetyt i wyobraźnię kulinarną klientów, w opisach potraw bardzo często wykorzystuje się leksemy o pozytywnych konotacjach, należące do dwóch podstawowych obszarów skojarzeń. Po pierwsze, związanych z domem rodzinnym (potrawy przygotowywane $\mathrm{w}$ domu zawsze kojarzone są $\mathrm{z}$ niepowtarzalnym smakiem; przywołują wspomnienia bezpiecznego i beztroskiego dzieciństwa); po drugie, z prostym, wiejskim jedzeniem, stereotypowo kojarzonym $z$ jadłem zdrowym, smacznym, przyrządzanym według tradycyjnych receptur, opartym na naturalnych i świeżych składnikach (pochodzących najlepiej z przydomowych ogródków czy pobliskich lasów). Takie pozytywne skojarzenia wywołują leksemy i konstrukcje typu: jak u mamy, od chłopa, domowy, swojski, wiejski, naturalny, świeży, tradycyjny, klasyczny, ogrodowy, prawdziwy:

jajecznica jak u mamy; buraczana polewka z czerwonych buraków od chłopa; domowe racuchy; domowe frytki; domowe kopytka; domowe kluseczki ugniatane ze 
szpinakiem; pieczeń cielęca krucha i delikatna w domowym sosie koperkowym; wątróbka wiśniowa podana z prażonymi jabłkami z domowej spiżarni; tradycyjne naleśniki z wiejskim białym serem; tradycyjne buraczki zasmażane; surówki ze świeżych warzyw; pstrąg tęczowy podany z wiejskimi frytkami; smaczna wariacja swojskiej kaszanki z jajkiem; sos carbonara na bazie naturalnie wędzonego polskiego boczku; borowiki z okolicznych lasów; klasyczna roladka ze śledzia; ogrodowy (tj. uprawiany w ogrodzie, a nie $z$ upraw przemysłowych) pomidor faszerowany mozzarellą z ziołami; gulasz wołowy serwowany z plackami ziemniaczanymi i łyżką gęstej wiejskiej śmietany; lody waniliowe z prawdziwą bitą śmietaną; tradycyjny żur polski.

Gwarancję jakości i rodzime pochodzenie składników podkreśla także wykorzystywany często przymiotnik polski o konotacjach 'bezpieczny w spożyciu, pochodzący z bezpiecznych upraw i hodowli’:

spaghetti z sosem bolognese przygotowanym na bazie polskiej selekcjonowanej wołowiny ${ }^{8}$; sandacz nasz polski na maśle; tradycyjna włoska lasagne z polską młodą wołowiną.

Do licznych należą także określenia wskazujące na walory potrawy, mówiące głównie o wysokiej jakości użytych do jej przyrządzania produktów i pieczołowitości w jej przygotowaniu:

delikatny comber z królika; subtelna cielęcina; pierś z kaczki najprzedniejszego gatunku; aksamitny sos borowikowy; delikatna panierka (przymiotnik delikatny ma tu łagodzić znaczenie boczku i panierki powszechnie uznawanych za niezdrowe - L.P.); wykwintna sałatka z rukoli; doskonałe pierogi; wyjątkowe danie kuchni żydowskiej; wykwintny bulion z kołdunami; płat doskonałego schabu; kurzy płat sosikiem z najprawdziwszych grzybów oblany; polędwica na grillu sprażona podawana $z$ wiejskim masełkiem i świeżo utartym czosnkiem; comber z sarny trzy noce marynowany w burgundzie; kurka wodna $\mathrm{z}$ naszym makaronem u nas na miejscu zagniecionym; polędwiczki wieprzowe długo marynowane; karczek nocą peklowany aż do skruszenia; wysublimowane piure $\mathrm{z}$ selera naciowego; polski ziemniak uszlachetniony włoskim sosem; szlachetne pierogi z cielęciną; królewski omlet ze szparagami.

Na wyrafinowanie, wyjątkowość, niepospolitość nawet zwykłych dań wskazują ponadto, odwołujące się do kategorii luksusu, przymiotniki: wysublimowany, wykwintny, doskonały, wyjątkowy, królewski, szlachetny.

Obecny współcześnie w mediach kult młodości i urody, propagowanie sprawności fizycznej oraz psychicznej, a także moda na zdrowy tryb życia, u podstaw

8 Prawdopodobnie w sformułowaniu tym pobrzmiewa echo panującej w latach 9o. XX w. w Europie Zachodniej epidemii BSE, tj. choroby szalonych krów, zagrażającej także zdrowiu ludzi, z powodu której w Polsce (i nie tylko) drastycznie spadło spożycie wołowiny, zwłaszcza tej sprowadzanej z zagranicy. 
czego leży właściwy sposób odżywiania, znajdują również odbicie w sposobie prezentowania produktów oferowanych klientom przez lokale gastronomiczne. Uwage zwracają informacje wskazujące na cechy potrawy - zgodne, co ważne, z najnowszymi tendencjami żywieniowymi (jak np. delikatne ciasto czekoladowe bez glutenu), określenia mówiące o prozdrowotnych i prowitalnych ${ }^{9}$ właściwościach potrawy lub napoju, a także podkreślające sposób oddziaływania potrawy/napoju. Koktajl porzeczkowy Oczyszczająca słodycz, jak można przeczytać w menu, „to rozkosz dla zmysłów i wspaniała odprężająca niespodzianka dla ciała. Energetyczna nuta czarnej porzeczki nie tylko rewelacyjnie smakuje w połączeniu ze słodyczą gruszki, ale przede wszystkim wspomaga usuwanie toksyn, a aromatyczne jagody niszczą niebezpieczne wolne rodniki i poprawiają pracę oczu. Dodatek żurawiny z kolei działa przeciwbakteryjnie i dopełnia kompozycji aksamitnej oczyszczającej owocowej słodyczy”. Koktajl z awokado o nazwie Moc afrodyzjaków z dodatkiem świeżego imbiru, selera, mięty i orzechów nerkowca „pobudza organizm”, „poprawia samopoczucie”, „podnosi libido”, „działa rozluźniająco i odprężająco”, „usprawnia krążenie krwi, wprawiając jednocześnie w lepszy nastrój”.

$\mathrm{W}$ restauracyjnych kartach $\mathrm{w}$ opisie potraw ważne, z punktu widzenia konsumenta, miejsce zajmują ponadto określenia informujące o liczbie użytych składników i dodatków, a także wskazujące na wielkości porcji (rozmiar dania):

wykwintny bulion z kołdunami suto zaprawionymi czosnkiem; gulasz wołowy z plackami ziemniaczanymi i łyżką wiejskiej śmietany; solidna porcja schabu; micha pierogów 30 sztuk; rodzinne koryto grillowanych mięs; sznycel wiedeński od brzega do brzega; gruby plaster miękkiego karczku; cieniutkie plastry marynowanej piersi kaczej.

Wizualizacji potrawy sprzyjają ponadto określenia wskazujące na sposób przyrządzenia i formę jej podania:

złocista golonka duszona $\mathrm{w}$ piwie; sałatka $\mathrm{z}$ buraków czerwonych marynowanych w wiśniach; mozzarella zapiekana w sosie pomidorowym w piecu opalanym drewnem; na żeliwnej patelence podajemy krewetki; dorada zapiekana w pergaminie aby zachować jej delikatność i soczystość; filetowany pstrąg pieczony w piecu; na żeliwie serwujemy różnorodność owoców morza; pieczony udziec wieprzowy serwowany na gorąco; jesiotr pieczony szpikowany bekonem wyeksponowany w całości na zimno; siekana polędwica wołowa, serwowana z żółtkiem na surowo, w towarzystwie drobno siekanych dodatków i masła; pikantny gulasz rybny serwowany w kokilce z gorącego pieczywa; plastry panierowanego bakłażana przekładane pomidorami, podawane na kolorowej sałacie; cielęcina duszona w śmietanie serwowana w kociołku; panierowany filet z kurczaka, serwowany na kapeluszach ogrodowych pieczarek w śmietanie; filet z pstrąga pieczony na kamieniu.

9 Określenia prozdrowotny i prowitalny przejęte za: Witaszek-Samborska 2005: 161. 
Przytoczone przykłady pokazują, że tradycyjny, stały sposób prezentacji potrawy w dawnych kartach dań, typu coś podane z lub na (najczęściej z sosem i zestawem surówek) zastępują dzisiaj opisy bardziej wyszukane, jak np.: serwowane/podane $w$ otoczeniu czegoś, $w$ towarzystwie, $w$ kompozycji, $w$ osnowie, $w$ mariażu, na pościeli:

chrupiąca kaczka w kompozycji konfitury z wina, jabłek i żurawiny; schab cielęcy $\mathrm{z}$ dodatkiem płatków owsianych, w mariażu warzywnego mirepoix; smażony filet $\mathrm{z}$ dorsza w towarzystwie bukietu jarzyn; stek $\mathrm{z}$ halibuta podany na risotto $\mathrm{z}$ borowikami w osnowie czerwonej cebuli i pomidorów suszonych.

Poprzez opis potrawy w menu dokonuje się niejako jej wizualizacja, zanim jeszcze klient otrzyma gotowe danie na talerzu. Toteż w analizowanych kartach dań opisy potraw są dobrze przemyślane, a żadne słowo nie jest przypadkowe. Opisy te oprócz podstawowej funkcji informacyjnej (informują o składnikach, dodatkach, sposobach przyrządzenia oraz podania potrawy czy jej właściwościach prozdrowotnych) pełnią także (a może przede wszystkim) funkcję perswazyjną - mają nakłonić potencjalnego klienta do konsumpcji.

Pobudzeniu apetytu i kulinarnej wyobraźni służą różne zabiegi. Przede wszystkim wykorzystuje się w tym celu środki leksykalne, zwłaszcza nazwy odwołujące się do cech organoleptycznych potrawy, których zadaniem jest pozytywne pobudzenie zmysłów, głównie tych związanych z jedzeniem - wzroku, smaku, węchu - ale także dotyku, a nawet słuchu. Niektóre leksemy, jak np. przymiotniki chrupiący czy wędzony, oddziałują na kilka zmysłów równocześnie: chrupkość potrawy można bowiem nie tylko usłyszeć, ale też i poczuć w ustach, a wędzenie rozpoznać za pomocą smaku i zapachu. Chętnie wykorzystywane w opisach dań jest też zjawisko synestezji, polegające na przenoszeniu wrażeń pochodzących z jednego zmysłu na inny, jak np. w metaforze orzeźwiająca nuta białych winogron, łączącej ze sobą wyrazy odsyłające do różnych zmysłów - smaku, słuchu i wzroku. Przy prezentacji walorów smakowych i zapachowych produktów poprzez działania językowe do głosu dochodzi niezwykle silna i bardzo skuteczna zarazem argumentacja emocjonalna, której trudno się oprzeć (Wierzchowska 1999: 114).

Innym skutecznym sposobem oddziaływania jest sięganie po leksemy pozytywnie wartościujące, budzące pozytywne skojarzenia, stąd celowe wywoływanie konotacji związanych z domem, dzieciństwem, młodością, swojskością, naturalnością, tradycją itp. To także kreowanie aury tajemniczości, oryginalności, stwarzanie pozoru luksusu i wyjątkowości. Na wyszukany czy wręcz ekskluzywny charakter potraw wskazują niecodziennie używane leksemy, jak: fantazja, uczta, mariaż, wyrafinowany, wysublimowany, wykwintny, wyselekcjonowany, uszlachetniony, zwieńczony, oprószony, muśnięty itp. 
W opisach potraw liczne są nazwy o charakterze metaforycznym, przeniesione do pola kulinariów z innych pól semantycznych. Przedmioty związane z życiem codziennym służą do interpretowania zjawisk należących do sfery kulinariów, np. metaforykę odzieżowo-sypialnianą (Witaszek-Samborska 2005: 132) wykorzystuje się do opisu produktów nadziewanych czymś, owijanych w coś lub podawanych na czymś: pierś kurczaka w pierzynce delikatnego boczku; jajka w koszulce, na pościeli $z$ rukoli i warzyw; polędwica $z$ dorsza $w$ cieście filo $z$ kurkami na łożu warzyw; natomiast składniki dań serwowane $\mathrm{z}$ dodatkiem sosu są zwykle przezeń otulone bądź utopione, zatopione, skąpane w..., np.: aromatyczny śmietanowy sos na bazie zielonego pieprzu otula mięso polędwiczki wieprzowej; karczek z pieca w sosie utopiony; żeberka duszone w sosie pieczeniowym skapane; gołąki faszerowane kurkami utopione $w$ rosole $z$ warzyw; polędwiczki wieprzowe zatopione w aksamitnym sosie borowikowym. W menu nie brak także określeń humorystycznych, jak: zawadiackie purée z gruszki; masłem sikajacy kotlet De Volaille czy wątróbka od wieprzaka abstynenta $w$ cebulce obtoczona.

Wszystkie te zabiegi sprawiają, że język analizowanych kart dań jest wyszukany i bardzo sensualny ${ }^{10}$, co czyni opisy potraw zmysłowo atrakcyjnymi.

Bogactwu i różnorodności środków leksykalnych towarzyszy natomiast schematyzm i raczej ograniczony repertuar modeli formalno-gramatycznych. Do najczęstszych należą struktury będące połączeniem nazw potraw z przymiotnikiem o znaczeniu melioratywnym (tak w przypadku nazw sensorycznych, odwołujących się do cech organoleptycznych potrawy) oraz konstrukcje z wyrażeniem przyimkowym, jak: coś z czymś, w czymś (wskazujące na składniki, surowce, dodatki do potrawy - lody waniliowe z goracymi truskawkami; golonka duszona w piwie; plastry pieczonego rozbefu w pieprzu młotkowanym), coś na czymś, pod czymśs (mówiące o sposobie podania potrawy - grillowana wątróbka na plastrach pomidora), z czegoś (informujące o sposobie przyrządzenia potrawy lub rodzaju użytych naczyń, sprzętów kuchennych - krewetki z rusztu; warzywa z patelni), a także konstrukcje imiesłowowe typu ravioli nadziewane szpinakiem, ogrodowy pomidor faszerowany mozzarella z ziołami.

Kształt językowy omawianych kart dań pokazuje, że współczesne menu to przemyślany i starannie przygotowany tekst reklamowy ${ }^{11}$, w którym odbicie znajdują różne, czasami przeciwstawne, zjawiska kulturowe charakterystyczne dla przełomu XX i XXI w. ${ }^{12}$, jak np.: kult młodości i witalizmu, powrót do tradycjonalizmu i lokalności, moda na rustykalizm i zdrowe odżywianie, zwrot ku naturze, ale także globalizm, czy kuchnia fusion.

10 Język opisu potraw w kartach dań może być różny i może zależeć (choć nie musi) od charakteru czy profilu restauracji.

11 Por. także Dawidziak-Kładoczna 2013.

12 Por. Witaszek-Samborska 2005: 164. 


\section{Analizowane materiały}

http://www.karczmabida.com/menu/opole/ (dostęp: 20 II 2020).

http://www.lastrada.com.pl/menu-desery.html (dostęp: 16 VII 2015).

http://restauracjagalicja.pl (dostęp: 16 VII 2015).

http://www.restauracjakonfitura.pl/kontakt.html (dostęp: 16 VII 2015).

http://alegloria.pl/menu (dostęp: 16 VII 2015).

http://www.czerwonywieprz.pl/pl/menu.html (dostęp: 16 VII 2015).

http://www.mazurkowachata.pl/zarelko (dostęp: 16 VII 2015).

\section{Literatura}

BRALCZYK J., 2004, Język na sprzedaż, Gdańsk.

DawidZIaK-KŁAdoczna M., 2013, Nazwy potraw a marketing. Perswazyjne środki językowe we współczesnym nazewnictwie gastronomicznym, „Prace Naukowe Akademii im. Jana Długosza w Częstochowie. Filologia Polska. Językoznawstwo” IX, s. 85-108.

DąBRowska A., 1998, O językowym zachowaniu się przy stole. Dlaczego upiększamy nazwy potraw, [w:] P. Kowalski (red.), Oczywisty urok biesiadowania, Wrocław, s. 248-253.

Lesz-Duk M., 2002, Słownictwo kulinarne we współczesnej polszczyźnie, „Prace Naukowe Wyższej Szkoły Pedagogicznej w Częstochowie. Filologia Polska. Językoznawstwo” IV, S. $175-180$.

LEWIŃsKi P.H., 1998, Smak zdrowia i raju, czyli o reklamie produktów spożywczych, [w:] P. Kowalski (red.), Oczywisty urok biesiadowania, Wrocław, s. 254-260.

Mitrenga B., 2014, Zmyst smaku. Studium leksykalno-semantyczne, Katowice.

WierzChowska M., 1999, „Niewypowiedzianie smaczne, nieopisanie pięknie pachnace” opis smaku i zapachu w komunikatach perswazyjnych na przykładzie tekstów reklam telewizyjnych, [w:] W. Gruszczyński, J. Bralczyk, G. Majkowska (red.), Polszczyzna w komunikowaniu publicznym. Prace poświęcone Profesor Halinie Satkiewicz z okazji jubileuszu Jej i Jej Zakładu, Warszawa, s. 107-114.

WitASZEK-SAMborska M., 2005, Studia nad słownictwem kulinarnym we współczesnej polszczyźnie, Poznań.

WójCickA M., 2010, Menu jako gatunek językowo-kulturowej wypowiedzi, [w:] R. Stolična, A. Drożdż (red.), Historie kuchenne. Rola i znaczenie pożywienia w kulturze, Cieszyn Katowice - Brno, s. 274-279.

\section{"Delight for the Senses" or the Language Used in Menus Summary}

This article is about language used in menus. The recently changing approach to cooking and eating is also reflected in language that describes food. Restaurant menus are a clear example of this. It is because eating, i. e. experiencing the taste of dishes, does not only take using our tongue, but it also involves using language. Some restaurant owners are aware of the relationship between taste and word, which is reflected in the way some dishes are described in menu cards offered to customers.

The purpose of the article is to analyse menus of selected restaurants and to show some linguistic tricks used by restaurant owners to encourage customers to eat in their restaurants. 